Jpn. J. Genet. (1985) 60, pp. 235-243

\title{
New shuttle vectors for Escherichia coli and Bacillus subtilis. II. Plasmid pHY300PLK, a multipurpose cloning vector with a polylinker, derived from pHY460
}

\author{
By Hiromi Ishiwa and Harue Shibahara \\ Yakult Institute for Microbiological Research, \\ 1796 Yaho, Kunitachi, Tokyo 186
}

(Received May 1, 1985)

\begin{abstract}
In vivo and in vitro recombination techniques were used to construct a new cloning vector, pHY300PLK $(4.7 \mathrm{~kb})$ from the shuttle vector pHY 460 $(7 \mathrm{~kb})$. The newly derived shuttle vector can replicate and express the tetracycline resistance gene $\left(\mathrm{Tc}^{\mathrm{R}}\right)$ in both Escherichia coli and Bacillus subtilis. pHY300PLK contains the $\mathrm{Tc}^{\mathrm{R}}$ gene, the ampicillin resistance gene $\left(\mathrm{Ap}^{\mathrm{R}}\right)$, two replication origins for $E$. coli and $B$. subtilis and a polylinker derived from $\pi$ AN7. The unique cloning sites are $B a l \mathrm{I}, B a m \mathrm{HI}, B a n \mathrm{I}, B g l \mathrm{I}, B g l \mathrm{II}$, BstEII, EcoRI, EcoRV, HindIII, HpaI, SalI, SmaI, PvuI and XbaI. pHY300 PLK is characterized as a copy-number mutant in $E$. coli. (Key words: shuttle vector; $B$. subtilis; tetracycline; ampicillin; copy-number mutant; incompatibility)
\end{abstract}

\section{INTRODUCTION}

At the first step of the gene manipulation in vitro, one must choose a good host-vector system for a desired foreign DNA. Many excellent cloning vectors in $E$. coli, are available. However, the expression of foreign DNA is often difficult in $E$. coli, and new host-vector systems need to be developed. Powerful gene manipulation systems have been developed in $E$. coli, so that bifunctional vectors between $E$. coli and other organisms are especially useful. Recently several bifunctional vectors have been developed. These include Bacillus subtilis (Ishiwa and Tsuchida 1984; Ostroff and Péne 1984 a,b), Streptococcus sanguis (Dao and Ferretti 1985), yeast (Broach et al. 1979; Heusterspreute et al. 1985) and several eukaryotic vectors (Gluzman 1982).

In the present communication we describe newly constructed shuttle vector, pHY300PLK $(4.7 \mathrm{~kb})$ derived from the shuttle vector pHY460 $(7 \mathrm{~kb})$. (1) pHY300PLK is one of the smallest shuttle vectors having two selective markers. (2) pHY300PLK is shown to be a copy-number mutant in $E$. coli, and can produce a large amount of plasmid DNAs in small culture. (3) In a $E$. coli $\mathrm{rec}^{+}$strain, the oligomer form DNAs are produced, which are effective

Abbreviations: Ap, ampicillin; kb, kilobase pairs; $\mathrm{Km}$, kanamycin; MIC, minimum inhibitory concentration; ori, origin of DNA replication; $\mathrm{R}$, resistance; $\mathrm{s}$, sensitivity; Tc, tetracycline; [ ], indicates plasmid-carrier state. 
in transforming competent cells of B. subtilis (Canosi et al. 1978; de Vos et al. 1981).

\section{MATERIALS AND METHODS}

(a) Bacterial strains and plasmids

The E. coli $\mathrm{K} 12$ strain $\mathrm{C} 600 \mathrm{~F}^{-}$thi-1 thr-1 pro leuB6 lac Y1 tonA21 supE44 $h s d R$ hsdM $\lambda^{-}$(Maniatis et al. 1982), the B. subtilis strain UOT0277 hisA1 metB5 recE4 nonB1 (Shimotsu et al. 1983) and plasmid vector pACYC177 (Chang and Cohen 1978) were provided by H. Saito and H. Yoshikawa (University of Tokyo). $\pi$ AN7 DNA (B. Seed, unpubl.) was provided by T. Sako (Yakult Institute).

(b) Cell growth

L-broth (Lennox 1955) was employed for routine cultivation of E. coli and B. subtilis.

(c) Preparation of plasmid DNA and transformation procedures of E. coli followed Maniatis et al. (1982) with minor modifications.

(d) Transformation procedures of Bacillus subtilis

The competent cells were prepared by the methods described in Sadaie and Kada (1983) with some modifications. When the cells had grown to the end of log phase in the first culture, $50 \%$ of glycerol was added to the culture to the final concentration of $12.5 \%$. A $0.4 \mathrm{ml}$ aliquot of the culture was dispensed into small plastic tubes and quickly frozen in a methanol-dry ice bath. The frozen cells were kept at $-80^{\circ} \mathrm{C}$ until use. The competent cells in the second culture were prepared from the frozen culture. The frozen culture was liquefied at $37^{\circ} \mathrm{C}$, the cells were harvested by centrifugation and then resuspended into $3 \mathrm{ml}$ of fresh SPII medium. The competent cells were obtained after 90 min of cultivation. The number of transformants were scored on L-agar containing $30 \mu \mathrm{g}$ of tetracycline per $\mathrm{ml}$. By using frozen cells, we could work rapidly and obtain highly reproducible results for more than six months.

\section{(e) Enzymes}

Restriction endonucleases were purchased from Boehringer-Mannheim (FRG), Bethesda Research Laboratories (Maryland, USA), New England Biolabs (Massachusetts, USA), Takara Shuzo (Kyoto, Japan), and Toyobo Co. Ltd., (Osaka, Japan). Enzymatic reactions were carried out under the conditions recommended by the suppliers. T4 DNA ligase, T4 DNA polymerase, HindIII linker were from Takara Shuzo and experimental conditions were followed by Maniatis et al. (1982). 


\section{RESULTS AND DISCUSSION}

Construction of shuttle vector $p H Y 300 P L K$ : In the previous paper (Ishiwa and Tsuchida 1984), we reported a shuttle vector pHY460 (7 kb) capable of replicating in both $E$. coli and $B$. subtilis from a fused plasmid of pACYC177 $\left(\mathrm{Ap}^{\mathrm{R}} \mathrm{Km}^{\mathrm{R}}\right)$ of $E$. coli and $\mathrm{pAM} \alpha 1\left(\mathrm{Tc}^{\mathrm{R}}\right)$ (Clewell et al. 1975) of Streptococcus faecalis. However, it was not always stable in B. subtilis when carying foreign DNA. Therefore, in an attempt to stabilize the vector we constructed several deletion plasmids from pHY460 as shown in Fig. 1. These plasmids

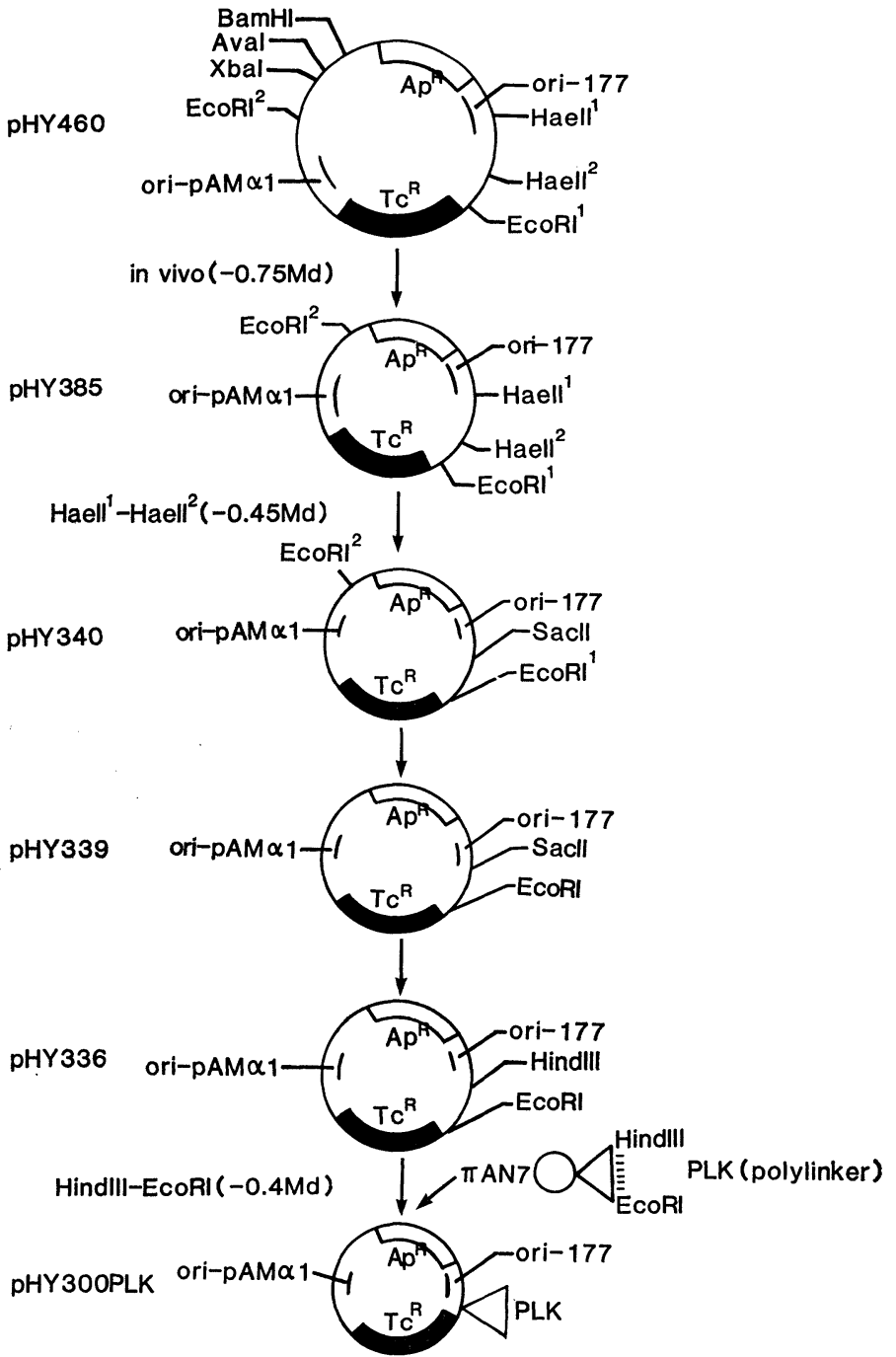

Fig. 1. Schematic diagrams of the family of $\mathrm{pHY}$ plasmids. Only those restriction sites are shown which are relevant for the construction. Functionally important regions are indicated as $A p^{R}, T^{R}$, ori-pAM $\alpha 1$, ori-177 and PLK(polylinker). 
retain main functional regions containing the replication origins of $\mathrm{pAM} \alpha 1$ (ori-pAM $\alpha 1$ ) and pACYC177 (ori-177), as well as the $\mathrm{Tc}^{\mathrm{R}}$ gene and the $\mathrm{Ap}^{\mathrm{R}}$ gene. In addition, the polylinker region from $\pi \mathrm{AN} 7$ was inserted into the smallest shuttle vector to get pHY300PLK $(4.7 \mathrm{~kb})$. pHY300PLK should be more suitable as a shuttle vector for use in both $E$. coli and $B$. subtilis. In the following, we will give some detailed descriptions about pHY300PLK (Fig. 1).

(a) Isolation of deletion plasmids in vivo from $\mathrm{pHY}_{4} 60$ : In the course of a stability test of pHY460 in $B$. subtilis, 48 clones were cultivated for about 50 generations in L-broth with $10 \mu \mathrm{g} / \mathrm{ml}$ of $\mathrm{Tc}$, and then the molecular size of the plasmids extracted from each culture was measured by agarose gel electrophoresis. Among them a deletion plasmid with molecular size of about $3.85 \mathrm{Md}(5.9 \mathrm{~kb})$ was isolated incidentally and named pHY385. pHY385 had lost the unique restriction sites of $X b a \mathrm{I}, A v a \mathrm{I}$ and $B a m \mathrm{HI}$ in pHY460 (Fig. 1). pHY385 DNA thus extracted from $B$. subtilis cells was able to transform E. coli cells to $\mathrm{Tc}^{\mathrm{R}} \mathrm{Ap}^{\mathrm{R}}$.

(b) Construction of deletion plasmids in vitro: The short HaeII fragment between the HaeII ${ }^{1}$ and $\mathrm{HaeII}^{2}$ sites was eliminated from $\mathrm{pHY} 385$. The new plasmid of about $3.4 \mathrm{Md}(5.2 \mathrm{~kb})$ was named pHY340; it was found to have the unique HaeII site.

To reduce the molecular size further and to introduce a polylinker into pHY340 vector, the following manipulations were performed. Since plasmid pHY340 contains two EcoRI sites (see EcoRI ${ }^{1}$ and EcoRI ${ }^{2}$ in Fig. 1), the circular plasmid DNA was cleaved with EcoRI under a condition allowing cleavage of the molecules at only one of the two sites. The full length linear DNA was purified by low-melting-point agarose gel electrophoresis and then treated with T4 DNA polymerase to fill in the cohesive ends. The DNA was ligated to the circular form, and used to transform E. coli to $\mathrm{Tc}^{\mathrm{R}} \mathrm{Ap}{ }^{\mathrm{R}}$. One of the plasmids from four clones tested as such had the unique EcoRI site and named $\mathrm{pHY} 339$.

To insert a HindIII linker into the SacII site of pHY339, plasmid pHY339 was digested with SacII, treated with T4 polymerase to fill in the cohesive ends, ligated with HindIII linkers and used to transform $E$. coli to $\mathrm{Tc}^{\mathrm{R}} \mathrm{Ap}^{\mathrm{R}}$. A plasmid which generated HindIII sites but had lost the SacII site was chosen. In order to keep a single HindIII site at the ligation point, it was treated with HindIII to remove the excess HindIII linkers, circularized with T4 DNA ligase, and amplified in $E$. coli. The new plasmid was named pHY 336. The polylinker region having a EcoRI site at one terminus and a HindIII site at the other terminus derived from $\pi \mathrm{AN} 7$ (Seed, B. unpubl.) was inserted into pHY336 DNA at the sites of HindIII and EcoRI by ligation, and the 


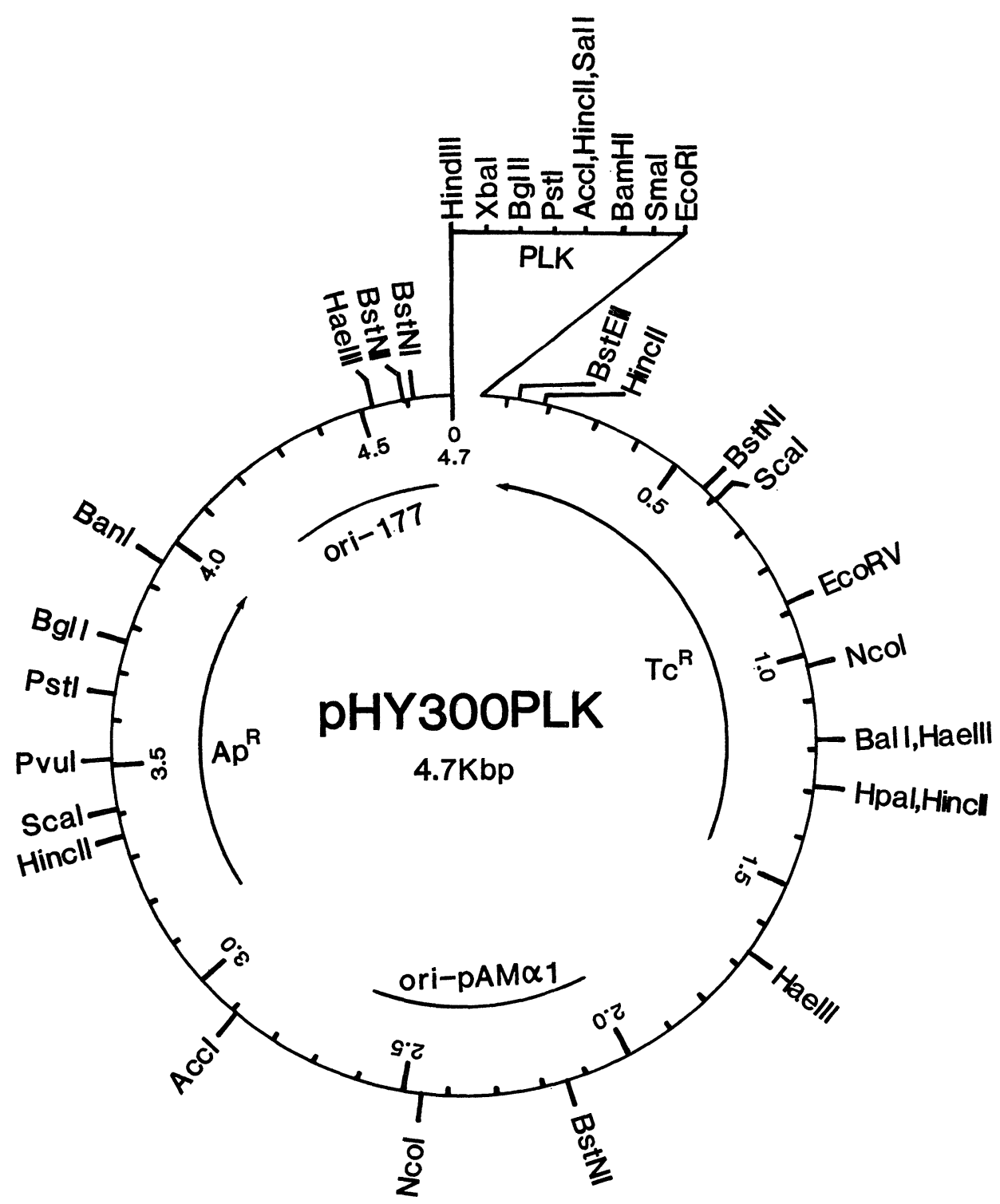

Fig. 2. The physical and genetic map of pHY300PLK. This plasmid specifies $\mathrm{Tc}^{\mathrm{R}}$ and $\mathrm{Ap}^{\mathrm{R}}$ in $E$. coli, and the origins of replication are designated ori-177 and ori-pAM $\alpha 1$.

recombinant DNA was used to transform $E$. coli cells to $\mathrm{Tc}^{\mathrm{R}} \mathrm{Ap}^{\mathrm{R}}$. These processes are shown in Fig. 1. One of the plasmids with a molecular weight of about $3 \mathrm{Md}(4.7 \mathrm{~kb})$ containing a polylinker region (HindIII-XbaI-BglII-PstISalI-BamHI-SmaI-EcoRI) was chosen and named pHY300PLK.

Restriction map of $p H Y 300 P L K$ : A restriction map of pHY300PLK (Fig. 2) was made from double and triple endonuclease digests of the plasmid DNA 
with help of pHY460 and its derivatives (Ishiwa and Tsuchida 1984). pHY 300PLK was found to have the unique substrate sites for BalI, BamHI, BanI, $B g l \mathrm{I}, B g l \mathrm{II}, B s t \mathrm{EII}, E c o$ RI, EcoRV, HindIII, HpaI, SalI, SmaI, PvuI and XbaI. The dual substrate sites were for $A c c \mathrm{I}$, NcoI, ScaI, PstI and PvuII. The following restriction sites were lacking; $A v a \mathrm{I}, A p a \mathrm{I}, B a n \mathrm{II}, B b e \mathrm{I}, B c l \mathrm{I}, K p n \mathrm{I}$, MulI, NruI, SacI, SlaI, StuI and Tth111I.

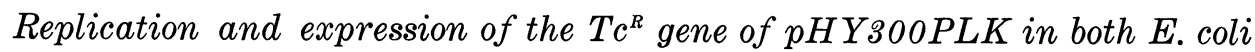
and B. subtilis: The plasmid DNA of pHY300PLK extracted from $E$. coli [pHY300PLK] was used to transform B. subtilis UOT0277. All of twelve $\mathrm{Tc}^{\mathrm{R}}$ transformants contained plasmids with a size of about $3 \mathrm{Md}(4.7 \mathrm{~kb})$. After shuttling between $E$. coli and $B$. subtilis, the molecular integrity of pHY300PLK DNA had well been conserved as determined based on the observations of molecular sizes and phenotypes.

MIC values, a mutation that affects for incompatibility and copy-number in E. coli: The minimum inhibitory concentration (MIC) values of Tc were determined by the tube dilution test method (Malke and Holm 1981) for strains of $E$. coli and $B$. subtilis which carried pHY340 or pHY300PLK. In the case of $E$. coli, $E$. coli [pHY300PLK] expressed a higher MIC value than $E$. coli [pHY340]. E. coli [pHY300PLK] was able to grow at the concentration $75 \mu \mathrm{g} / \mathrm{ml}$ of Tc but not at $100 \mu \mathrm{g} / \mathrm{ml}$ of Tc in L-broth. It means that the MIC value of Tc for E. coli [pHY300PLK] should be between 75 and $100 \mu \mathrm{g} /$ $\mathrm{ml}$. Thus, we put $\mathrm{MIC}=100 \mu \mathrm{g} / \mathrm{ml}$ tentatively. Similarly, the MIC value of $E$. coli [pHY340] was between 25 and 30 ; then $\mathrm{MIC}=30 \mu \mathrm{g} / \mathrm{ml}$.

We have experienced a relatively higher plasmid yield from $E$. coli $[\mathrm{pHY}$ $300 \mathrm{PLK}$ ] than $E$. coli [pHY340] in a plasmid isolation procedure throughout the course of the present experiments. Therefore it was suggested that a higher MIC value of $E$. coli [pHY300PLK] compared with that of $E$. coli [pHY 340] could be explained in terms of gene dose effect due to a copy-number mutation in the RNA I region of the ori-177 region. Actually, the nucleotide sequence analysis of pHY300PLK (H. I., in preparation) has revealed that there is a single base substitution in the regulatory RNA I when compared with the ori-p15A (Selzer et al. 1983). Note that pACYC177 was derived from the p15A replicon (Chang and Cohen 1978). The whole sequence of pHY300PLK will be published elsewhere.

Copy number mutations in the RNA I region usually have altered incompatibility and vice versa in ColEl as reviewed by Davison (1984). This could be the case in the present mutation found in pHY300PLK. Double transformation experiments described below clearly showed that the nature of incompatibility of pHY300PLK was changed to be compatible. First, pACYC177 $\left(\mathrm{Ap}^{\mathrm{R}} \mathrm{Km}^{\mathrm{R}}\right)$ was able to transform $E$. coli $\left[\mathrm{pHY} 300 \mathrm{PLK}\left(\mathrm{Tc}^{\mathrm{R}} \mathrm{Ap}^{\mathrm{R}}\right)\right]$ to $\mathrm{Tc}^{\mathrm{R}} \mathrm{Ap}^{\mathrm{R}}$ 
$\mathrm{Km}^{\mathrm{R}}$. Furthermore, DNAs extracted from double transformants showed two species of molecules corresponding to each plasmid. Secondly, in a series of transformation experiments in the reverse direction, no transformants were obtained. These results suggest that functional RNA I produced by pACYC 177 repressed the initiation of DNA replication of pHY300PLK which was introduced later. The segregation test (Tomizawa and Itoh 1981) has not been done for doubly transformed bacteria.

As in the case of pACYC177 reported by Chang and Cohen (1978), pHY300 PLK was found to undergo only limited amplification in the presence of chloramphenicol $(\mathrm{Cm})$. However, we can easily obtain a large amount of the plasmid DNA and its derivatives in $E$. coli by cultivating them in L-broth overnight at $37^{\circ} \mathrm{C}$ without an addition of $\mathrm{Cm}$.

MIC values for B. subtilis: MIC values of Tc for B. subtilis UOT0277 carrying pHY340 or pHY300PLK were also determined in a similar way to that for E. coli. B. subtilis [pHY340] grew at $150 \mu \mathrm{g} / \mathrm{ml}$ of Tc in L-broth with aeration but not at $200 \mu \mathrm{g} / \mathrm{ml}$; thus MIC was estimated to be $200 \mu \mathrm{g} / \mathrm{ml}$. $B$. subtilis [pHY300PLK] grew at $100 \mu \mathrm{g} / \mathrm{ml}$ of Tc but not at $150 \mu \mathrm{g} / \mathrm{ml}(\mathrm{MIC}=$ 150). The plasmid-free strain of B. subtilis was sensitive to Tc and its MIC value was lower than $12.5 \mu \mathrm{g} / \mathrm{ml}$ in this study. In contrast to the case of $E$. coli, MIC value of $B$. subtilis [pHY300PLK] turned out to be slightly smaller than that of B. subtilis [pHY340]. This difference of MIC values was reproducible and should be meaningful. From the nucleotide sequence analysis of the $\mathrm{Tc}^{\mathrm{R}}$ determinant in $\mathrm{pHY} 300 \mathrm{PLK}$ (H.I., in preparation), the terminal codon of a long open reading frame for $\mathrm{Tc}^{\mathrm{R}}$ was found about 50 bases upstream of the EcoRI site, and a possible terminator sequence with a hairpin structure (Rosenberg and Court 1979) was discovered between the terminal codon and the EcoRI site (Fig. 3). In the process of construction (Fig. 1), the region of about 700 bp between the EcoRI ${ }^{1}$ site and the sacII site in $\mathrm{pHY} 340$ had been

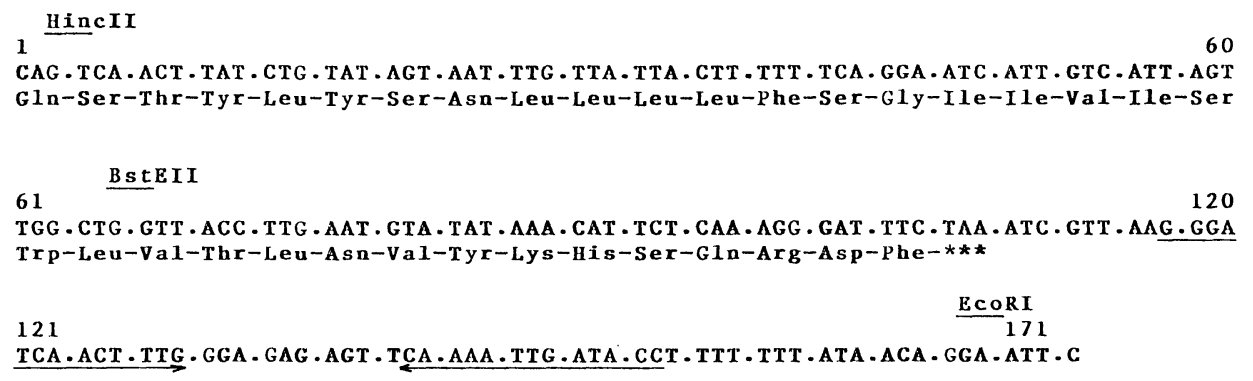

Fig. 3. Terminator sequence of $\mathrm{Tc}^{\mathrm{R}}$ determinant originated from $\mathrm{pAM} \alpha 1$. The antisense strand for the terminator regin between HincII and EcoRI sites is shown. The inverted repeat sequences are underlined, and the $\mathrm{T}$ residues are found (Rosenberg and Court 1979). 
deleted in pHY300PLK, which made up most of the differences around the Tc gene between the two vectors. Thus, it is suggested that due to this deletion $B$. subtilis [pHY300PLK] showed slightly lower resistance to Tc. If this is the case, there might exist some signal which is functional only in B. subtilis for enhancing the expression of the $\mathrm{Tc}^{\mathrm{R}}$ gene within the $700 \mathrm{bp}$ region. To clarify this point further we need more experimental data.

A successful system for transformation: In constrast to the report by Chang and Cohen (1978), pACYC177 and a series of pHY plasmids in our study formed multimers about $30 \%$ in the $\mathrm{rec}^{+}$strain but very rarely in the rec $A$ strain of $E$. coli. Only the oligomer form DNAs could be transformed into $B$. subtilis competent cells with high efficiency (Canosi, et al. 1978; de Vos et al. 1981). Accordingly, the shuttle vector DNA which is amplified in the rec ${ }^{+}$ strain of $E$. coli is suitable as a donor DNA for transforming B. subtilis competent cells. Crude DNAs extracted from a small scale culture of a $E$. coli rec ${ }^{+}$ strain are sufficient enough to use for transformation into both $E$. coli and $B$. subtilis. In addition, frozen competent cells of $B$. subtilis processed by our method have continued to give good transformation results for more than six months and thus are recommended to use. By using the shuttle vector, $\mathrm{pHY}$ 300PLK amplified in any E. coli $\mathrm{rec}^{+}$strain with frozen competent cells, the transformation procedure for $B$. subtilis has become just as easy as for $E$. coli.

In conclusion, we have established a new shuttle vector "system", which is useful for gene coloning in $E$. coli and B. subtilis simultaneously.

pHY300PLK is one of the smallest shuttle vectors so far available. However, pHY300PLK shortened even further, while retaining some of functionally essential regions. The result will be published elsewhere.

We wish to express our thanks to Drs. H. Saito and H. Yoshikawa, for their generous supplying the bacterial strains and plasmids. We wish to thank to Dr. T. Sako for his gift of $\pi$ AN7 DNA. We also wish to thank Drs. A. B. Jacobson, A. Hirashima, M. Shimizu-Kadota and T. Osawa for their critical reading the manuscript. We are thankful to Dr. M. Mutai for his encouragement throughout the course of the work.

\section{REFERENCES}

Broach, J. R., Strathern, J. N. and Hicks, J. B. (1979) Transformation in yeast: development of a hybrid cloning vector and isolation of the can1 gene. Gene 8, 121-133.

Canosi, U., Morelli, G. and Trautner, T. A. (1978) The relationship between molecular structure and transformation efficiency of some $S$. aureus plasmids isolated from $B$. subtilis. Mol. Gen. Genet. 166, 259-267.

Chang, A. C. Y. and CoHen, S. N. (1978) Construction and characterization of amplifiable multicopy DNA cloning vehicles derived from the P15A cryptic miniplasmid. J. Bacteriol. 134, 1141-1156.

Clewell, D. B., YAgi, Y. and BAuer, B. (1975) Plasmid-determined tetracycline resistance in Streptococcus faecalis: evidence for gene amplification during growth in presence of tetracycline. Proc. Natl. Acad. Sci. USA 72, 1720-1724. 
DaO, M. L. and FerRetTI, J. J. (1985) Streptococcus-Escherichia coli shuttle vector pSA3 and its use in the cloning of streptococcal genes. Appl. Environ. Microbiol. 49, 115-119.

DAvison, J. (1984) Mechanism of control of DNA replication and incompatibility in ColEl-type plasmids-a review. Gene 28, 1-15.

de Vos, W. M., Venema, G., Canosi, U. and Trautner, T. A. (1981) Plasmid transformation in Bacillus subtilis: fate of plasmid DNA. Mol. Gen. Genet. 181, 424-433.

GLuzman, Y. (1982) Eukaryotic viral vectors Cold Spring Harbor Laboratory, Cold Spring Harbor, NY.

Heusterspreute, M., Oberto, J., Ha-Thi, V. and Davison, J. (1985) Vectors with restrictionsite banks. III. Escherichia coli-Saccharomyces cerevisiae shuttle vectors. Gene 34, 363366.

Ishiwa, H. and Tsuchida, N. (1984) New shuttle vectors for Escherichia coli and Bacillus subtilis.. I. Construction and characterization of plasmid pHY 460 with twelve unique cloning sites. Gene 32, 129-134.

Lennox, E. S. (1955) Transduction of linked genetic characters of the host by bacteriophage Pl. Virology 1, 190-206.

MALKE, H. and HoLm, S. E. (1981) Expression of streptococcoal plasmid-determined resistance to erythromycin and lincomycin in Escherichia coli. Mol. Gen. Genet. 184, 283-295.

Maniatis, T., Fritsch, E. F. and Sambrook, J. (1982) Molecular Cloning, A Laboratory Manual. Cold Spring Harbor Laboratory, Cold Spring Harbor, NY.

OStroff, G. R. and PÉNE, J. J. (1984a) Molecular cloning with bifunctional plasmid vectors in Bacillus subtilis, I. Construction and analysis of B. subtilis clone banks in Escherichia coli. Mol. Gen. Genet. 193, 299-305.

OStroff, G. R. and PÉNe, J. J. (1984b) Molecular cloning with bifunctional plasmid vectors in Bacillus subtilis, II. Transfer of sequences propagated in Escherichia coli to B. subtilis. Mol. Gen. Genet. 193, 306-311.

Rosenberg, M. and Court, D. (1979) Regulatory sequences involved in the promotion and termination of RNA transcription. Ann. Rev. Genet. 13, 319-353.

SAdAIE, Y. and KADA, T. (1983) Formation of competent Bacillus subtilis cells. J. Bacteriol. $153,813-821$.

Selzer, G., Soм, T., Iтон, T. and Tomizawa, J. (1983) The origin of replication of plasmid p15A and comparative studies on the nucleotide sequences around the origin of related plasmids. Cell 32, 119-129.

Shimotsu, H., Kawamura, F., Kobayashi, Y. and Saito, H. (1983) Early, sporulation gene spo $O F$ : nucleotide sequence and analysis of gene product. Proc. Natl. Acad. Sci. USA 80, 658662.

Tomizawa, J. and Iтон, T. (1981) Plasmid ColEl incompatibility determined by interaction of RNA I with primer transcript. Proc. Natl. Acad. Sci. USA 78, 6069-6100. 